\title{
What Does VECM Technique Reveal About India And Russia With Regard To Capital Inflows?
}

\author{
Dolly Sunny \\ Professor of Economics, University of Mumbai and \\ Indian Council of Social Science Research- WRC \\ CST Road, Kalina, Santacruz East Mumbai 400098, Maharashtra, India.
}

\author{
Anupama Unnikrishnan \\ Ph.D., University of Mumbai \\ Högsbogatan 30 Läg 009, 41475 Göteborg, Sweden
}

\begin{abstract}
This paper tries to identify the determinants of capital inflows in India and Russia using vector autoregression technique. First two parts provide an overview of Russian and Indian economies by highlighting the earlier studies conducted. Third part describes the research methodology whereas the fourth part explains the data and variables used for the research. Fifth and sixth parts deal with the results and conclusion respectively. The paper emphasizes on the necessity of both the countries cooperating together to overcome the negative impacts of the factors highlighted in the paper to reap benefits in future.
\end{abstract}

Keywords: capital inflows; vector autoregression technique; India; Russia. JEL Code: F3

\section{AN OVERVIEW OF INDIAN ECONOMY}

India is fast approaching to acquire the status of an open-market economy. Policies initiated in 1990s such as industrial deregulation, privatization of state-owned enterprises, and reduced controls on foreign trade and investment, have a great role in accelerating the country's yearly growth, to 7 percent since 1997. Traditional village farming, modern agriculture, handicrafts, a wide range of modern industries, and a multitude of services are the characteristics of Indian economy. The Indian economy did not undergo much adverse impact from the global financial crisis owing to large part because of strong domestic demand. Infact growth exceeded 8 percent year-on-year in real terms. In 2011 slowing down of economic growth was visible because of a slowdown in government spending and a decline in investment, due to negative by investor pessimism. High international crude prices resulted in higher fiscal deficit and a worsening current account deficit. To overcome the deficit problem and to reverse India's slowdown, higher levels of foreign participation in direct investment in the economy was allowed in 2012. With outward looking policy measure which is in progress to well connect India with countries of abroad, time has come to attract more FDI inflows to India. (Government of India, 2016).

\section{AN OVERVIEW OF RUSSIAN ECONOMY}

Russia has deviated from the erstwhile collapse of the Soviet Union, deviating from a globallyisolated, centrally-planned economy to a more market-based and globally connected economy. Economic reforms undertaken in Russia in the 1990s resulted in privatisation of the industry to a greater extent. It cannot be denied that the private sector is still under heavy state 
interference. In 2011, Russia overtook Saudi Arabia in oil produce. Russia has the distinction of the world's largest natural gas reserves, the second-largest coal reserves, and the eighthlargest crude oil reserves. Russia exports metals like steel and primary aluminum to a great extent. The Russian government put special efforts in developing country's high technology sectors since 2007. The Russian economy, has most adverse hit as a result of 2008-09 global economic crisis when oil prices plummeted and the foreign credits declined. By the end of 2009, Russia could come out of it. By 2011-12, Russia could reduce unemployment inflation to a greater extent. Adoption of a new oil-price-based fiscal rule in 2012 and a more flexible exchange rate policy have improved its ability to deal with external shocks. (Government of India, 2016).

\section{India-Russia ties}

Seventy years ago, India and Russia established diplomatic relations. The Soviet Union helped India in many ways to become more self-reliant and remained as a true partner of India. Both India and Russia have acquired a new self-confidence due to their rapid economic growth. India-Russia cooperation, particularly in the defence sector, helped both the countries. Russia remains India's largest supplier of military equipment despite the entry of US and Israel. IndoRussian energy cooperation is also expected to get a boost in the coming years. According to the estimation of International Energy Agency, India would be the third largest energy consumer in the world by 2025 after US and China. Russia is destined to play a vital role in ensuring India's energy security in the coming decades. India is an energy deficient country, whereas Russia is energy surplus, and therefore, a mutual interest lies in this sector. IndoRussian cooperation with regard to trade and economic ties is weak. Trade between the two countries is extremely low. India and Russia are already trying to boost the economic partnership through Comprehensive Economic Partnership Agreement (CEPA). Russia's move to encourage the promotion of groupings like RIC (Russia-India-China) and BRICS enable India and Russia to discuss issues more freely. The bilateral ties between Russia and India within the context of multilateral formats like the G-20, BRICS, Shanghai Cooperation Organisation and RIC, formed the cornerstone of the foreign policies of both countries in 2016. The IndianRussian trade and economic linkages remain weak inspite of mutual cooperation in many other fields. Total bilateral trade is about $\$ 6.7$ billion (2015), which is extremely low. While Russia makes up just 1 per cent of India's total trade, India accounts for only 1.2 per cent of Russia's overall trade as on 2015-2016.(Government of India, 2016). In order to realize the trade and investment target, India and Russia should take the lead in finalising the India-Eurasian Economic Union (EEU) and Free Trade Agreement (FTA), encompassing trade in goods, trade in services and investment, which would serve as a catalyst for enhancing the levels of economic linkages between India and Russia, but also of the Eurasian region.

\section{Economic Relations}

In December 2014, the leaders of India and Russia set a target of US $\$ 30$ billion bilateral trade by 2025. Bilateral trade during in 2015 amounted to US\$ 7.83 billion (decline of $17.74 \%$ over 2015), with Indian export amounting to US $\$ 2.26$ billion and imports from Russia amounting to US\$ 5.57\%. Major items of export from India ranges from pharmaceuticals, tea, coffee and tobacco, nuclear reactors \& boilers, machinery and mechanical appliances, organic chemicals, and electrical machinery to equipments. The import from Russia include pearls, precious and semi-precious stones \& metals, nuclear power equipment, electrical machinery and equipment, mineral oil \& products, iron \& steels, and optical, precision and surgical equipment. (Government of India, 2016). 


\section{EARLIER STUDIES}

Traditional literatures on capital inflows are bifurcated into two categories external(push) and internal factors (pull). At the macroeconomic level, capital inflows are expected to be welfare improving but it can also act as a double-edged sword. The behavior of capital inflows in the long and the short run has been under study.

Calvo et al (1993) discussed the capital flows to Latin America. The study finds that the economic conditions in the advanced economies i.e. push factors as well the macroeconomic conditions of recipient countries i.e. pull factors are both significant in determining capital inflows. It was concluded that the inflows in Latin America countries were partly explained by recession in the United States and lower national interest rates. Balkan et al (2002) argue that capital volume of international trade does not have any noteworthy impact on short term capital flows and higher capital mobility leads to exchange rate risk.

Hooper and Kim (2006) examine the relationship between foreign capital flows and the opacity of recipient countries. Using the opacity index for the year 2000 the study analyses the impact of the index on foreign direct investment, portfolio capital and international bank lending. The results suggest higher opacity leads to reduction in capital inflows in some cases whereas the study finds that in some economies with an increase in opacity relating to business climate drives in more capital inflows. Canela et al (2006) explain portfolio flows allocation towards emerging countries. Canela et al (2006) used panel data analysis to assess the local and global factors influencing portfolio capital flows to BRIC economies. It is found that portfolio capital flows are principally driven by global risk factors, openness and short term interest rates. Frankel (2008) illustrates a potential link between strong commodity prices and low real interest rates. Brana and Lahet (2010) investigated the impacts of both external factors and domestic fundamentals on the evolution of capital inflows with a panel of four Asian countries over the period of (1990-2007). The study states that push factors as carry trade strategies, global liquidity and contagion factors, are major determinants of capital inflows into Asia.

Fratzscher (2011) analyse the portfolio capital flows to fifty economies and find that global financial crisis and changes to global liquidity and risk have had a huge impact on capital flows. The study further states that the effect has been diverse across fifty economies considered for the study. Luca and Spatafora (2012) investigate the interaction between capital inflows, financial development and domestic investment in developing countries. They state that increase in net capital inflows and domestic credit is due to reduction in global price of risk and domestic borrowing costs. They argue that neither greater domestic credit nor greater institutional quality increase the extent to which capital inflows translate into domestic investment.

\section{RESEARCH METHODOLOGY}

This research tries to identify main determinants of capital inflows in India and China using Vector Autoregression (VAR) technique. Johansen cointegration and Augmented Dickey fuller test are used for data analysis. The Vector Error Correction model (VECM) which is a restricted VAR is used for the analysis since Johansen cointegration test suggested cointegration among the variables in the long run for BRICS. The lag length of the model is determined by performing Schwarz Information Criterion. Impulse response function is used to gauge the effects of shocks on capital inflows with World Bank's annual data (1995-2014).

The variables used in the study include capital inflows (sum of FDI, portfolio equity and other inflows), inflation (INFL), exchange rate (ER), gross capital formation (GCF) and growth rate of 
gross domestic product (GGDP).Except GGDP all other variables were transformed into log values. All the variables are constant at 2010 U.S. dollars. All the diagnostic testing done for BRICS countries made it relevant to estimate the equations using OLS estimate. Data for FDI, portfolio equity and other investment was available in current prices, it was converted to constant prices using GDP deflator. This research tries to identify main determinants of capital inflows in BRICS using Vector Autoregression (VAR) technique. Johansen cointegration and Augmented Dickey fuller test are also used for data analyses.

\section{Vector autoregression}

Vector autoregression (VAR) was introduced by Sims (1980) as a technique that could be used by macroeconomists to characterize the joint dynamic behavior of a collection of variables without requiring strong restrictions of the kind needed to identify underlying structural parameters. It has become a prevalent method of time-series modeling. (Johansen, 1995).

\section{VAR Models (reduced form)}

$$
Y_{t}={ }_{1} Y_{t 1}+\ldots+{ }_{p} Y_{t p}+\mathrm{a}_{t}
$$

Structural VAR Model

Consider a bivariate $\mathrm{Y}_{\mathrm{t}}=\left(\mathrm{y}_{\mathrm{t}}, \mathrm{x}_{\mathrm{t}}\right)$, first-order VAR model:

$$
\begin{array}{ll}
\mathrm{y}_{\mathrm{t}}=\mathrm{b}_{10} & \mathrm{~b}_{12} \mathrm{x}_{\mathrm{t}}+{ }_{11} \mathrm{y}_{\mathrm{t} 1}+{ }_{12} \mathrm{x}_{\mathrm{t} 1}+{ }_{\mathrm{yt}} \\
\mathrm{x}_{\mathrm{t}}=\mathrm{b}_{20} & \mathrm{~b}_{21} \mathrm{y}_{\mathrm{t}}+{ }_{21} \mathrm{y}_{\mathrm{t} 1}+{ }_{22} \mathrm{x}_{\mathrm{t} 1}+{ }_{\mathrm{xt}}
\end{array}
$$

The error terms (structural shocks) $\varepsilon_{y t}$ and $\varepsilon_{x t}$ are white noise innovations with standard deviations $\sigma_{\mathrm{y}}$ and $\sigma_{\mathrm{x}}$ and a zero covariance. The two variables $\mathrm{y}$ and $\mathrm{x}$ are endogenous. Shock $\varepsilon_{y t}$ affects y directly and $x$ indirectly. The structural VAR is not a reduced form. In a reduced form representation $\mathrm{y}$ and $\mathrm{x}$ are just functions of lagged $\mathrm{y}$ and $\mathrm{x}$. To solve for a reduced form write the structural VAR in matrix form as:

$$
\begin{aligned}
& \begin{array}{ccc}
1 & b_{12} & y_{t} \\
b_{21} & 1 & x_{t}
\end{array}=\begin{array}{l}
b_{10} \\
b_{20}
\end{array}+\begin{array}{llll}
11 & 12 & y_{t 1} \\
& & & \\
21 & 22 & x_{t 1}
\end{array}{ }_{x t}{ }_{x t} \\
& B Y_{t}={ }_{0}+{ }_{1} Y_{t 1}+{ }_{t}
\end{aligned}
$$

Pre-multipicationby $\mathrm{B}^{-1}$ allow us to obtain a standard VAR(1):

$$
\begin{aligned}
& B Y_{t}={ }_{0}+{ }_{1} Y_{t 1}+{ }_{t} \\
& Y_{t}=B^{{ }_{1}}{ }_{0}+B^{1}{ }_{1} Y_{t 1}+B^{1}{ }_{t} \\
& Y_{t}={ }_{0}+{ }_{1} Y_{t 1}+a_{t}
\end{aligned}
$$

This is the reduced form which will be estimated using OLS

$$
\begin{aligned}
& \operatorname{VAR}(\mathrm{p}): \quad Y_{t}=c+{ }_{1} Y_{t 1}+{ }_{2} Y_{t_{2}}+\ldots .{ }_{p} Y_{t p}+a_{t} \\
& E\left(a_{t}\right)=0 \quad E\left(a_{t} a^{\prime}\right)={ }_{0} t=
\end{aligned}
$$




$$
i_{1}=\begin{array}{llll}
\text { are matrices } \\
11 & 12 & 13 & \\
21 & 22 & 23 \\
31 & 32 & 33
\end{array}
$$

When the variables of a VAR are cointegrated, we use a vector error-correction (VEC) model. A VEC for two variables might look like:

$$
\begin{aligned}
& \Delta y_{t}=\beta_{y 0}+\beta_{y 1} \Delta y_{t-1}+\cdots+\beta_{y p} \Delta y_{t-p}+\gamma_{y 1} \Delta x_{t-1}+\cdots+\gamma_{y p} \Delta x_{t-p}-\lambda_{y}\left(y_{t-1}-\alpha_{0}-\alpha_{1} x_{t-1}\right)+v_{t}^{y} \\
& \Delta x=\beta_{x 0}+\beta_{x 1} \Delta y_{t-1}+\cdots+\beta_{x p} \Delta y_{t-p}+\gamma_{x 1} \Delta x_{t-1}+\cdots+{ }_{x p} \Delta x_{t-p}-\lambda_{x}\left(y_{t-1}-\alpha_{0}-\alpha_{1} x_{t-1}\right)+v_{t}^{x}
\end{aligned}
$$

Where $y_{t}=\alpha_{0}+\alpha_{1} x_{t}$ is the long-run cointegrating relationship between the two variables $\lambda_{x}$ and $\lambda_{y}$ are the error-correction parameters that measure how $\mathrm{y}$ and $\mathrm{x}$ react to deviations from long-run equilibrium. When we apply the VEC model to more than two variables, we must consider the possibility that more than one cointegrating relationship exists among the variables. (Sims, 1980).

\section{Generation of impulse response functions}

The Impulse Response Functions (IRF) are generated to forecast the future values of endogenous variables when one standard deviation shock is imposed in the system. Variance decomposition is also performed to show the breakdown of the forecast error variance for a specific time horizon. It helps in depicting the short-term and long-term impacts on of one variable on another variable of interest. (Sims, 1980).

Impulse-response functions (IRFs) measure the dynamic marginal effects of each shock on all of the variables over time. Variance decompositions examine how important each of the shocks is as a component of the overall (unpredictable) variance of each of the variables over time.

If the VAR is stable, then the IRFs should converge to zero as the time from the shock s gets large-one-time shocks should not have permanent effects. As noted above, non-convergent IRFs and unstable VARs are indications of non-stationarity in the variables of the model, which may be corrected by differencing. (Sims, 1980).

IRFs are usually presented graphically with the time lag s running from zero up to some userset limit $S$ on the horizontal axis and the impact at the s-order lag on the vertical. They can also be expressed in tabular form if the numbers themselves are important. One common format for the entire collection of IRFs corresponding to a VAR is as an $\mathrm{n} \times \mathrm{n}$ matrix of graphs, with the "impulse variable" (the shock) on one dimension and the "response variable" on the other. (Sims, 1980). 


\section{Impulse Response Functions}

$Y_{t}=c+{ }_{1} Y_{t 1}+{ }_{2} Y_{t_{2}}+\ldots .+{ }_{p} Y_{t p}+a_{t}$

If the system is stable,

$Y_{t}=+(L) a_{t}=+a_{t}+{ }_{1} a_{t 1}+{ }_{2} a_{t 2}+\ldots$

$(L)=[(L)]^{1}$

Redating at time $t+s$ :

$Y_{t+s}=+a_{t+s}+{ }_{1} a_{t+s 1}+{ }_{2} a_{t+s 2}+\ldots .+{ }_{s} a_{t}+{ }_{s+1} a_{t 1}+\ldots$.

$\frac{Y_{t+s}}{a_{t}^{\prime}}={ }_{s}=\left[\begin{array}{c}{ }_{i j}(s) \\ { }^{\prime}\end{array}\right] \quad \longrightarrow \quad$ (multipliers)

$\frac{y_{i, t+s}}{a_{j t}}={ }_{i j}^{(s)} \quad \longrightarrow$ Reaction of the $\mathrm{i}$-variable to a unit change in innovation $\mathrm{j}$

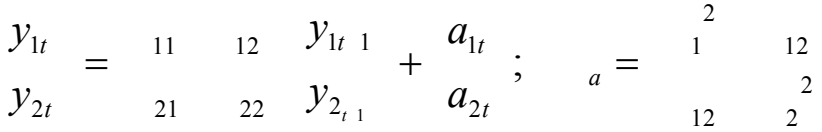

\section{Reaction of the system}

$$
\begin{aligned}
& \begin{array}{l}
y_{10}=\begin{array}{l}
0 \\
y_{20}
\end{array} \\
1
\end{array}
\end{aligned}
$$

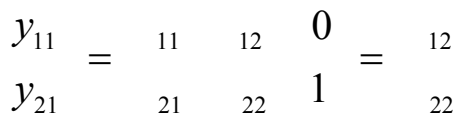

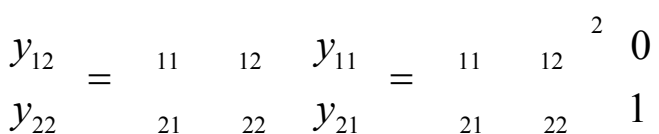

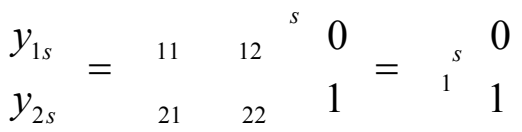

$$
\begin{aligned}
& (L)=[(L)]^{1} \\
& 1=1 \\
& { }_{2}={ }_{1}^{2} \\
& { }_{s}=s_{1}
\end{aligned}
$$

\section{DATA}

This research uses World Bank data for a period ranging from 1995 to 2014. The variables used in the research are described in the next section. 


\section{Capital Inflows: India and Russia}

The capital inflows ranging from the period 1995 to 2014 is portrayed in Table 1 in case of both emerging economies of India and Russia. The value of capital inflows constituted in the case of India and Russia had commendable difference during the period of analysis as portrayed in Table 1 . The period of analysis witnessed downward and upward variations in the values. By the end of the period of analysis, i.e., by 2014, India's capital inflows was observed to be 998072361 whereas Russia experienced a negative trend in capital inflows. The observations with regard to capital inflows of both countries as given in table 1 are depicted with the help of chart in figure 1.

Table 1: Capital Inflows in Russia and India (1995-2014)

(in millions/US\$)

\begin{tabular}{|c|c|c|}
\hline Year & India & Russia \\
\hline 1995 & 87671869 & -74829031 \\
\hline 1996 & 281608100 & 191720718 \\
\hline 1997 & 238801379 & 575472788 \\
\hline 1998 & 205030730 & 137453750 \\
\hline 1999 & 174513543 & -99903980 \\
\hline 2000 & 243499234 & -481092143 \\
\hline 2001 & 169217691 & -21097602 \\
\hline 2002 & 146631206 & 147613421 \\
\hline 2003 & 216685805 & 788612627 \\
\hline 2004 & 311229824 & 799689118 \\
\hline 2005 & 449469280 & 1018610090 \\
\hline 2006 & 727757638 & 1097837677 \\
\hline 2007 & 1089624051 & 2453854933 \\
\hline 2008 & 615270899 & 1057644316 \\
\hline 2009 & 679975814 & 235303022 \\
\hline 2010 & 1057816848 & 556076800 \\
\hline 2011 & 899493989 & 667777243 \\
\hline 2012 & 1193898143 & 837960287 \\
\hline 2013 & 949310311 & 995568476 \\
\hline 2014 & 998072361 & -223181777 \\
\hline
\end{tabular}

Source: World Development Indicators (2017), World Bank, USA

Figure 1: Capital Inflows in Russia and India (1995-2014)

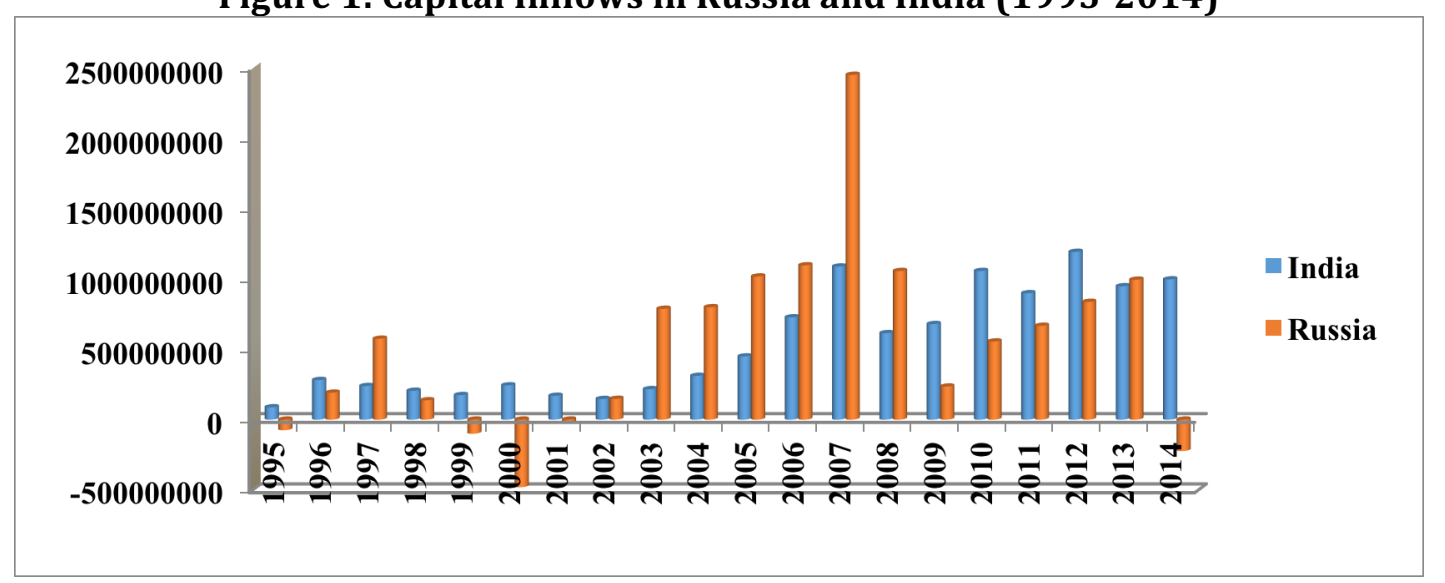

Source: Derived from Table 1 


\section{Exchange Rate: India and Russia}

The fluctuations in exchange rate during the period of analysis in both countries India and Russia is portrayed in table 2 and by way of figure 2 . As indicated in the table, when the exchange rate of India corresponded to 3.47 at the commencement of the period of analysis in 1995, that of Russia was 1.15. The exchange rate values of both countries increased by the end of the analysis in 2014. It can be observed from table 2 that the value of India increased to 4.11, followed by mild fluctuations by way of insignificant ups and downs and that of Russia increased to 3.64. The value of exchange rate for both countries increased from the year 1998 as depicted in table 2 .

Table 2: Exchange Rate in Russia and India (1995-2014)

(in millions/US\$)

\begin{tabular}{|c|c|c|}
\hline Year & India & Russia \\
\hline 1995 & 3.478994 & 1.517136 \\
\hline 1996 & 3.567648 & 1.633317 \\
\hline 1997 & 3.592184 & 1.75524 \\
\hline 1998 & 3.719878 & 2.27265 \\
\hline 1999 & 3.762488 & 3.203555 \\
\hline 2000 & 3.805364 & 3.336807 \\
\hline 2001 & 3.854106 & 3.37309 \\
\hline 2002 & 3.883836 & 3.445166 \\
\hline 2003 & 3.841242 & 3.424003 \\
\hline 2004 & 3.81367 & 3.360852 \\
\hline 2005 & 3.786459 & 3.342312 \\
\hline 2006 & 3.813462 & 3.302885 \\
\hline 2007 & 3.722037 & 3.241844 \\
\hline 2008 & 3.77288 & 3.212973 \\
\hline 2009 & 3.879609 & 3.457589 \\
\hline 2010 & 3.822663 & 3.413387 \\
\hline 2011 & 3.843112 & 3.380394 \\
\hline 2012 & 3.978508 & 3.428807 \\
\hline 2013 & 4.070698 & 3.460634 \\
\hline 2014 & 4.111358 & 3.64749 \\
\hline
\end{tabular}

Source: World Development Indicators (2017), World Bank, USA

Figure 2: Exchange Rate in Russia and India (1995-2014)

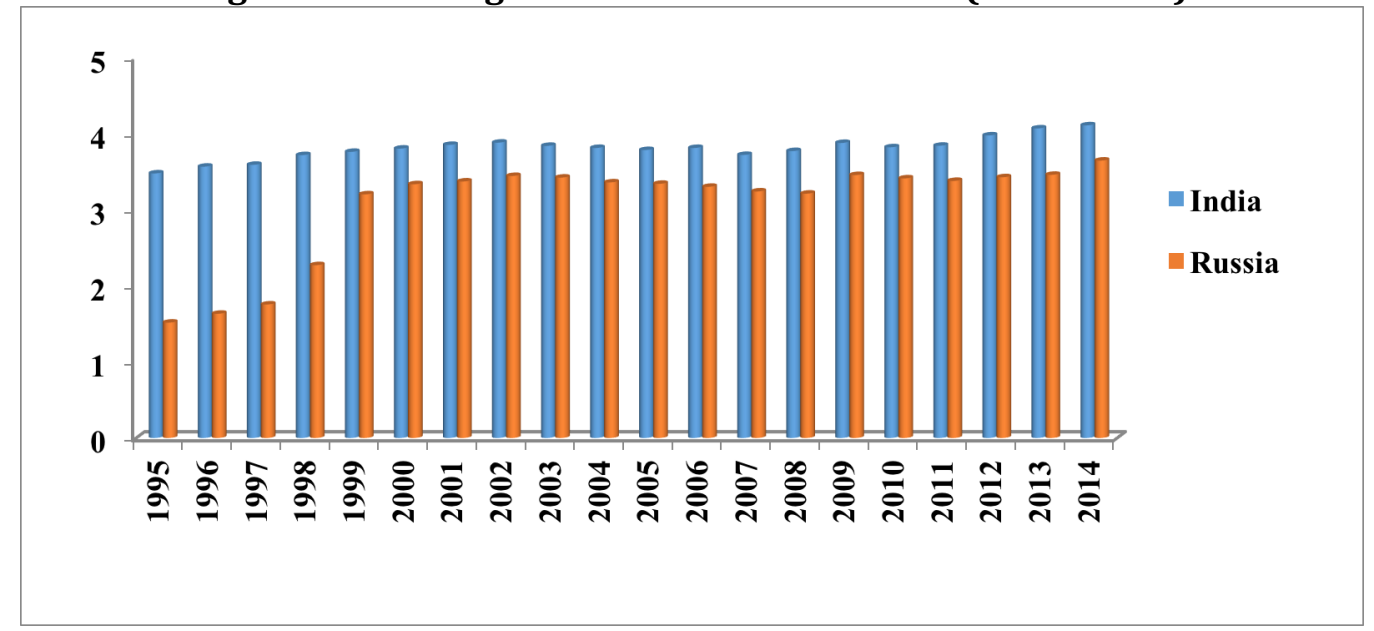

Source: Derived from Table 2 


\section{Gross Capital Formation: India and Russia}

Figure 3 and table 3 summaries the fluctuations in gross capital formation over the two decades in the case of countries India and Russia. During the beginning of the period of analysis, gross capital formation of Russia was higher than India. The pattern of gross capital formation in the case of India showed an increasing trend while that of Russia depicted a decrease till 2002. In case of Russia, gross capital formation showed an increasing trend after 2003. By the end of the period of analysis, India's growth in gross capital formation represented an increase when compared to that of Russia.

Figure 3: Gross Capital Formation in Russia and India (1995-2014)

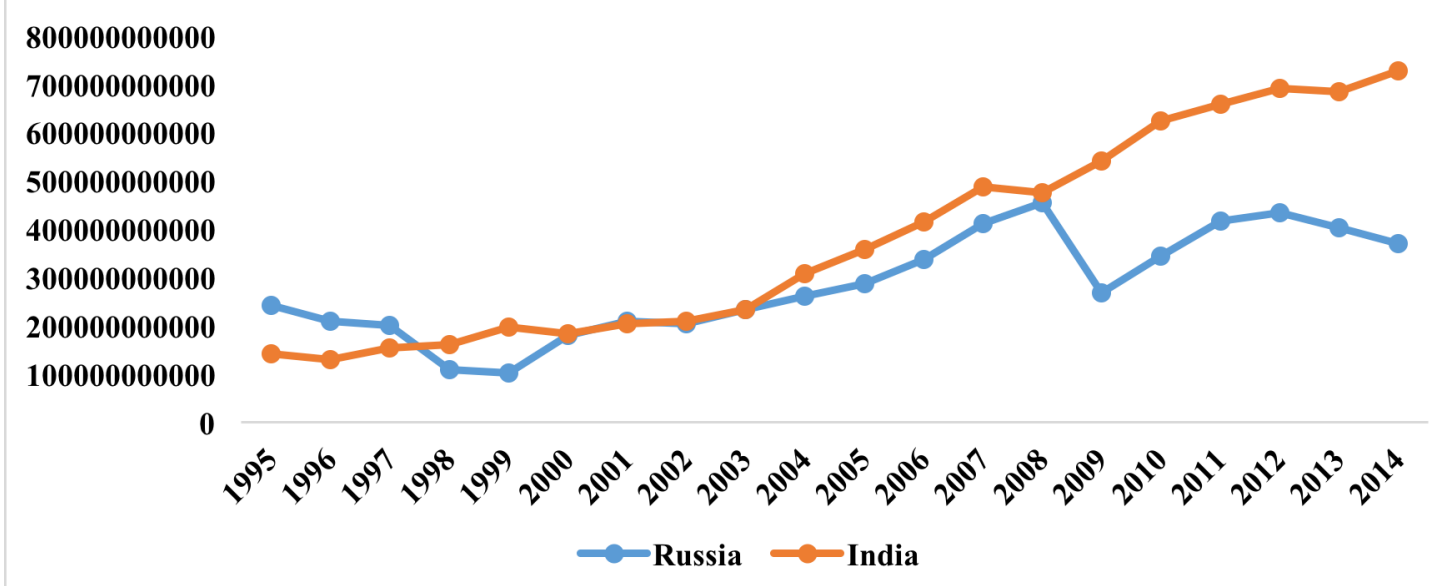

Source: Derived from Table 3

Table 3: Gross Capital Formation in Russia and India (1995-2014) (in millions/US\$)

\begin{tabular}{|c|c|c|}
\hline Year & India & Russia \\
\hline 1995 & 142387561921 & 242844670647 \\
\hline 1996 & 129765446700 & 208846416756 \\
\hline 1997 & 153454473582 & 200283713667 \\
\hline 1998 & 161383632187 & 109755475093 \\
\hline 1999 & 196837601334 & 102511613730 \\
\hline 2000 & 183514103465 & 179600347259 \\
\hline 2001 & 203677617169 & 209663054577 \\
\hline 2002 & 209502948083 & 204144171515 \\
\hline 2003 & 234068619893 & 233336788045 \\
\hline 2004 & 308363165916 & 261803876180 \\
\hline 2005 & 358618140965 & 286675244416 \\
\hline 2006 & 414342719587 & 337416762682 \\
\hline 2007 & 487751064705 & 411648450472 \\
\hline 2008 & 476437490552 & 454871537778 \\
\hline 2009 & 541033757991 & 268374207283 \\
\hline 2010 & 624073148566 & 344860856365 \\
\hline 2011 & 659188644095 & 417281636195 \\
\hline 2012 & 692012034061 & 433725114084 \\
\hline 2013 & 685114867894 & 402261180697 \\
\hline 2014 & 728580059654 & 370140234844 \\
\hline
\end{tabular}

Source: World Development Indicators (2017), World Bank, USA 


\section{Growth of GDP: India and Russia}

While considering the GGDP over the period under comparison, the pattern and quantum of growth underwent significantly different style. The growth rate of GDP in case of Russia showed a negative trend for four years, i.e., 1995, 1996, 1998 and 2009. The growth rate of Russia was maximum in the year 2000 whereas for India it was in the year 2010. The trend and pattern of GGDP for India and Russia are portrayed in table 4 and figure 4.

Table 4: Growth of GDP in Russia and India (1995-2014)

(in millions/US\$)

\begin{tabular}{|c|c|c|}
\hline Year & India & Russia \\
\hline 2002 & 3.803975 & 4.74367 \\
\hline 2000 & 3.840991 & 10 \\
\hline 2008 & 3.890957 & 5.247954 \\
\hline 1997 & 4.049821 & 1.4 \\
\hline 2001 & 4.823966 & 5.091984 \\
\hline 2012 & 5.618563 & 3.517942 \\
\hline 1998 & 6.184416 & -5.3 \\
\hline 2011 & 6.638353 & 4.264177 \\
\hline 2013 & 6.638813 & 1.279454 \\
\hline 2014 & 7.243472 & 0.706371 \\
\hline 1996 & 7.549522 & -3.6 \\
\hline 1995 & 7.574492 & -4.14353 \\
\hline 2003 & 7.860381 & 7.295854 \\
\hline 2004 & 7.922937 & 7.175949 \\
\hline 2009 & 8.479787 & -7.82089 \\
\hline 2007 & 8.608212 & 8.53508 \\
\hline 1999 & 8.845756 & 6.4 \\
\hline 2006 & 9.263959 & 8.153432 \\
\hline 2005 & 9.284832 & 6.376187 \\
\hline 2010 & 10.25996 & 4.503726 \\
\hline
\end{tabular}

Source: World Development Indicators (2017), World Bank, USA

Figure 4: Growth of GDP in Russia and India (1995-2014)

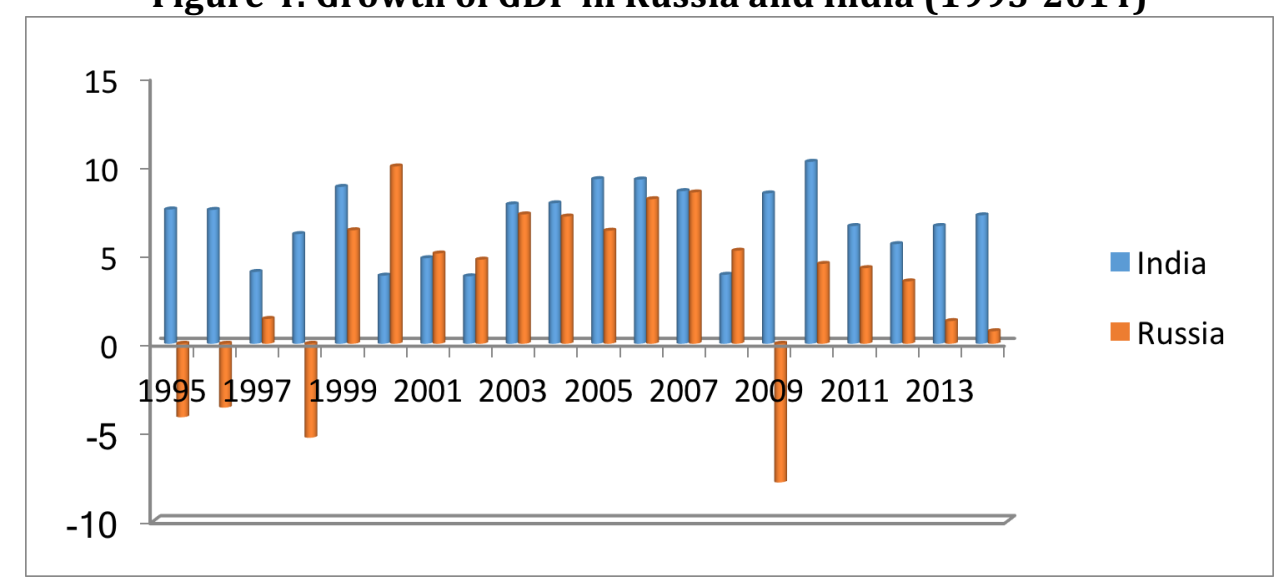

Source: Derived from Table 4

\section{1.e Inflation: India and Russia}

The trend of inflation in Russia and India is depicted in table 5 and figure 5 . The rate of inflation in both countries, Russia and India, during the beginning period of analysis, i.e., 1995 
was observed to 197.47 and 10.22 respectively. It can be observed from figure 5 that Russia experienced hyperinflation. This can be attributed to the expansion of the money supply by the central bank of Russia and instability in Russian monetary policy caused the variations in the rate of inflation. The rate of inflation was observed to be minimum in the year 2001 in the case of India and 2012 in the case of Russia. It can be observed from table 5 that rate of inflation in both countries was characterized by ups and downs during the period of analysis.

Table 5: Inflation in Russia and India (1995-2014)

\begin{tabular}{|c|c|c|}
\hline Year & India & Russia \\
\hline 2012 & 9.31 & 5.07 \\
\hline 2013 & 10.91 & 6.76 \\
\hline 2010 & 11.99 & 6.86 \\
\hline 2014 & 6.35 & 7.83 \\
\hline 2011 & 8.86 & 8.44 \\
\hline 2007 & 6.37 & 9.01 \\
\hline 2006 & 6.15 & 9.68 \\
\hline 2004 & 3.77 & 10.86 \\
\hline 2009 & 10.88 & 11.65 \\
\hline 2005 & 4.25 & 12.68 \\
\hline 2003 & 3.81 & 13.68 \\
\hline 2008 & 8.35 & 14.11 \\
\hline 1997 & 7.16 & 14.77 \\
\hline 2002 & 4.39 & 15.79 \\
\hline 2000 & 4.01 & 20.78 \\
\hline 2001 & 3.68 & 21.46 \\
\hline 1998 & 13.23 & 27.67 \\
\hline 1996 & 8.98 & 47.74 \\
\hline 1999 & 4.67 & 85.74 \\
\hline 1995 & 10.22 & 197.47 \\
\hline
\end{tabular}

Source: World Development Indicators (2017), World Bank, USA

Figure 5: Inflation in Russia and India

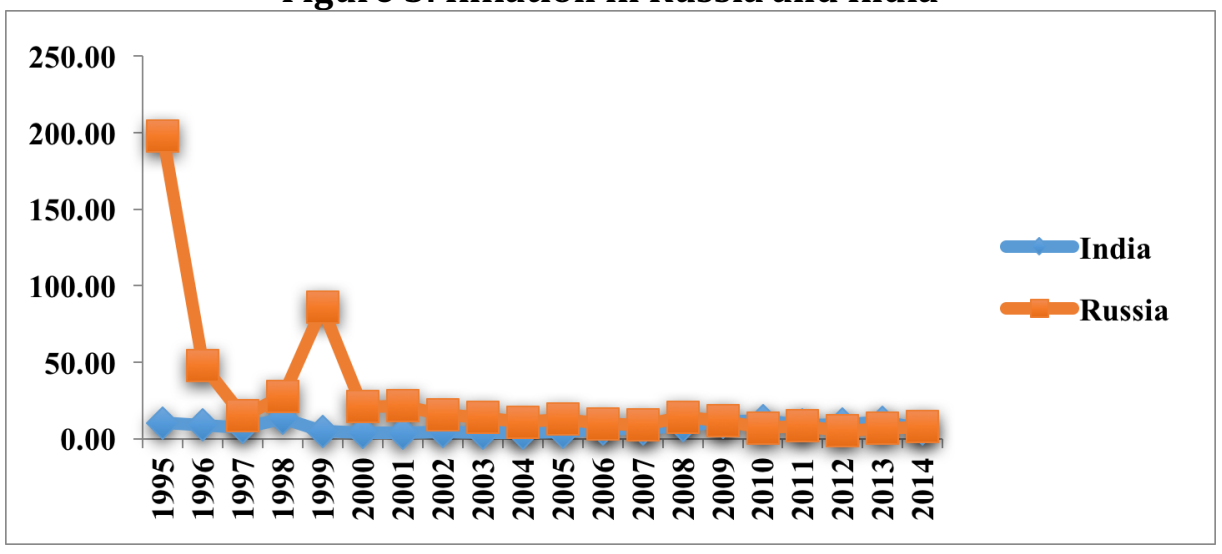

Source: Derived from Table 5 


\section{RESULTS}

The Vector Error Correction model (VECM) is used for the analysis since Johansen cointegration test suggested cointegration among the variables in the long run for BRICS. VECM results give the dependence of all variables to the lagged values of each other. The $\mathrm{R}^{2}$ for BRICS was found to be more than 60 percent which indicates that the model was fitted properly. The lag length of the model is determined by performing Schwarz Information Criterion. The Impulse Response Functions (IRF) are generated to forecast the future values of endogenous variables when one standard deviation shock is imposed in the system. Variance decomposition is also performed to show the breakdown of the forecast error variance for a specific time horizon. It helps in depicting the short-term and long-term impacts on of one variable on another variable of interest.

\section{Highlights on Indian Economy}

Indian economy witnessed an increase in capital inflows in 2007-08. In 2008 it experienced a fall due to economic crisis of 2008. Net capital inflows, which increased from 2.2 percent of GDP in 1990-91 to around 9 percent in 2007-08. According to Mohan (2008), much of this increase has been offset by corresponding capital outflows, largely on account of foreign institutional investors' (FIIs) portfolio investment transactions, Indian investment abroad and repayment of external borrowings.

For Indian economy the unit root test suggested capital inflows (0.0001), GCF (0.0004), inflation (0.0007), GGDP (0.0003) and exchange rate (0.01) to be stationary at first difference. The results are shown in table 5. The results of Johansen cointegration test shown in table 6 shows existence of three cointegrating equation in Indian economy model.

Table 5: Results of Augmented Dickey Fuller test- India

\begin{tabular}{|c|c|c|}
\hline Variable & t-statistics & p-value \\
\hline $\mathrm{D}(\mathrm{CI})$ & -6.273024 & 0.0001 \\
\hline $\mathrm{D}(\mathrm{GGDP})$ & -5.568839 & 0.0003 \\
\hline $\mathrm{D}(\mathrm{GCF})$ & -5.353706 & 0.0004 \\
\hline $\mathrm{D}(\mathrm{INFL})$ & -5.133952 & 0.0007 \\
\hline $\mathrm{D}(\mathrm{ER})$ & -3.655977 & 0.0144 \\
\hline
\end{tabular}

Source: Computed with the help of Eviews

Table 6: Results of Johansen Cointegration test- India

\begin{tabular}{|c|c|c|c|}
\hline $\begin{array}{c}\text { Hypothesized } \\
\text { No. of CE(s) }\end{array}$ & Eigenvalue & $\begin{array}{c}\text { Trace } \\
\text { Statistic }\end{array}$ & Probability \\
\hline None & 0.948650 & 133.8851 & 0.0000 \\
\hline At most 1 & 0.907675 & 80.44159 & 0.0000 \\
\hline At most 2 & 0.713533 & 37.55775 & 0.0052 \\
\hline At most 3 & 0.475299 & 15.05538 & 0.0581 \\
\hline At most 4 & 0.174266 & 3.446685 & 0.0634 \\
\hline
\end{tabular}

Source: Computed with the help of Eviews

The results of VECM estimates for Indian economy are shown in table 7. It suggests that capital inflows in Indian economy is determined by GGDP and exchange rate. It was also found that capital inflows in Indian economy is associated in the long run with GGDP, inflation and exchange rate. 
TABLE 7: ESTIMATES OF VECTOR ERROR CORRECTION MODEL

\begin{tabular}{crrr} 
CointegratingEq: & CointEq1 & CointEq2 & CointEq3 \\
\hline \hline LNCI(-1) & 1.000000 & 0.000000 & 0.000000 \\
GGDP(-1) & 0.000000 & 1.000000 & 0.000000 \\
LNGCF(-1) & 0.000000 & 0.000000 & 1.000000 \\
LNINFL(-1) & -2.045839 & -6.570307 & -0.377539 \\
& $(0.45625)$ & $(1.90611)$ & $(0.12366)$ \\
& {$[-4.48405]$} & {$[-3.44697]$} & {$[-3.05302]$} \\
LNER(-1) & -9.878507 & -40.10619 & -1.788574 \\
& $(1.99904)$ & $(8.35159)$ & $(0.54182)$ \\
C & {$[-4.94162]$} & {$[-4.80222]$} & {$[-3.30105]$} \\
& 0.199737 & 1.393967 & -0.027129
\end{tabular}

\begin{tabular}{|c|c|c|c|c|c|}
\hline Error Correction: & $\mathrm{D}(\mathrm{LNCI})$ & D(GGDP) & $\mathrm{D}(\mathrm{LNGCF})$ & D(LNINFL) & D(LNER) \\
\hline \multirow[t]{3}{*}{ CointEq1 } & -0.737677 & 0.343250 & 0.164046 & 0.741602 & 0.075523 \\
\hline & $(0.31844)$ & $(0.33763)$ & $(0.06106)$ & $(0.29817)$ & $(0.04895)$ \\
\hline & {$[-2.31656]$} & [ 1.01663$]$ & {$[2.68684]$} & [2.48718] & [ 1.54295$]$ \\
\hline \multirow[t]{3}{*}{ CointEq2 } & 0.236432 & -0.237077 & 0.072922 & -0.176862 & -0.015453 \\
\hline & $(0.10648)$ & $(0.78165)$ & $(0.02042)$ & $(0.09970)$ & $(0.01637)$ \\
\hline & [ 2.22047] & {$[-0.30330]$} & [3.57188] & {$[-1.77392]$} & [-0.94418] \\
\hline \multirow[t]{3}{*}{ CointEq3 } & -0.772121 & -0.919828 & -2.055353 & 0.077510 & 0.188469 \\
\hline & $(0.48839)$ & $(0.2672)$ & $(0.47711)$ & $(0.33002)$ & $(0.38249)$ \\
\hline & {$[-1.5809]$} & {$[-3.44247]$} & {$[-4.30791]$} & {$[0.23486]$} & [0.49274] \\
\hline \multirow[t]{3}{*}{$\mathrm{D}(\mathrm{LNCI}(-1))$} & -0.363222 & -0.097837 & -0.130112 & -0.211652 & -0.088352 \\
\hline & $(0.25870)$ & $(0.89912)$ & $(0.04960)$ & $(0.24224)$ & $(0.03977)$ \\
\hline & {$[-1.40402]$} & {$[-0.108814]$} & {$[-2.62311]$} & {$[-0.87374]$} & {$[-2.22185]$} \\
\hline \multirow[t]{3}{*}{$\mathrm{D}(\mathrm{GGDP}(-1))$} & -0.104085 & -0.452499 & -0.024733 & 0.073506 & 0.009164 \\
\hline & $(0.05414)$ & $(0.39742)$ & $(0.01038)$ & $(0.05069)$ & $(0.00832)$ \\
\hline & {$[-1.92259]$} & {$[-1.13858]$} & {$[-2.38274]$} & [1.45005] & [ 1.10126$]$ \\
\hline \multirow[t]{3}{*}{$\mathrm{D}(\operatorname{LNGCF}(-1))$} & 0.376189 & 0.240164 & 0.322260 & 0.629619 & -0.307937 \\
\hline & $(0.29588)$ & $(0.51303)$ & $(0.24847)$ & $(1.21341)$ & $(0.19919)$ \\
\hline & {$[1.27141]$} & [0.46812] & {$[1.29700]$} & [0.51889] & {$[-1.54594]$} \\
\hline \multirow[t]{3}{*}{ D(LNINFL(-1)) } & -0.200960 & 0.426400 & 0.110815 & -0.356533 & 0.009683 \\
\hline & $(0.24796)$ & $(0.82025)$ & $(0.04754)$ & $(0.23218)$ & $(0.03811)$ \\
\hline & {$[-0.81046]$} & [0.51983] & [ 2.33088] & {$[-1.53561]$} & [0.25405] \\
\hline \multirow[t]{3}{*}{ D(LNER(-1)) } & 0.114573 & 0.45032 & 0.153671 & 0.168288 & -0.242864 \\
\hline & $(0.01598)$ & $(0.7993)$ & $(0.38653)$ & $(0.88767)$ & $(0.30988)$ \\
\hline & [ 7.16842] & [ 0.56341$]$ & [0.39756] & [ 0.18958$]$ & {$[-0.78374]$} \\
\hline \multirow[t]{3}{*}{$\mathrm{C}$} & -0.061314 & 0.061668 & 0.010098 & -0.012922 & -0.003104 \\
\hline & $(0.07857)$ & $(0.57675)$ & $(0.01506)$ & $(0.07357)$ & $(0.01208)$ \\
\hline & {$[-0.78041]$} & [0.10692] & {$[0.67036]$} & {$[-0.17565]$} & {$[-0.25704]$} \\
\hline
\end{tabular}

Source: Computed with the help of Eviews

For Indian economy when one standard deviation shock was imposed on GGDP and exchange rate, capital inflows showed a positive trend for ten years whereas it showed a negative trend with regard to GCF. In case of response of capital inflows to inflation, it was positive for first 4 years then negative for one year and again positive which is depicted in the figure given below. 
FIGURE 6: IMPULSE RESPONSE FUNCTION- INDIA

Response of $\mathrm{LNCl}$ to Cholesky

One S.D. Innovations

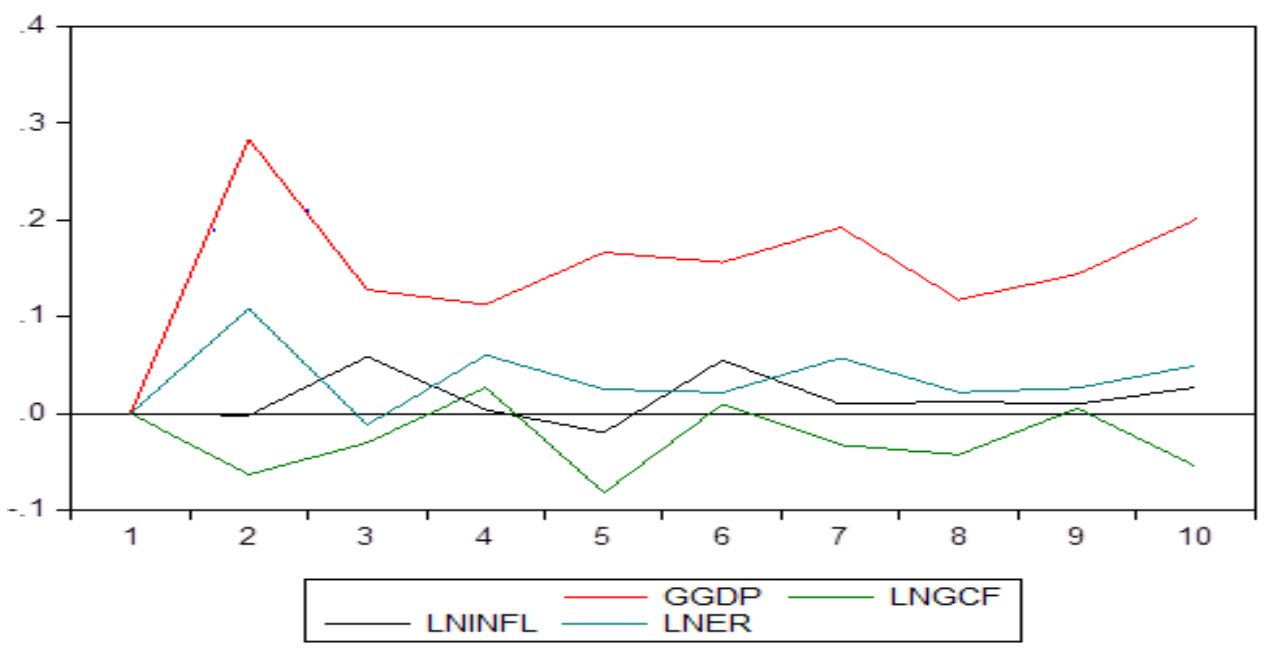

Table 8 shows the results of variance decomposition test for Indian economy over a period of 10 years. The test results suggest that the impact of GGDP in the short and long run was found to be steady. Inflation and exchange rate are found to influence capital inflows in the short run but eventually the impact reduces in the long run. The impact if GCF in capital inflows is found to decrease in the long run.

Table 8: Variance Decomposition- India

\begin{tabular}{|c|c|c|c|c|c|c|}
\hline Period & S.E. & CI & GGDP & GCF & INFL & ER \\
\hline 1 & 0.328612 & 100.0000 & 0.000000 & 0.000000 & 0.000000 & 0.000000 \\
\hline 2 & 0.470917 & 56.53635 & 36.35943 & 1.793683 & 0.001843 & 5.308694 \\
\hline 3 & 0.571513 & 64.09749 & 29.70180 & 1.494270 & 1.060222 & 3.646217 \\
\hline 4 & 0.617948 & 64.79471 & 28.74645 & 1.466037 & 0.911126 & 4.081676 \\
\hline 5 & 0.686964 & 64.00466 & 29.13735 & 2.602002 & 0.818821 & 3.437168 \\
\hline 6 & 0.753035 & 65.09570 & 28.55986 & 2.181312 & 1.219529 & 2.943597 \\
\hline 7 & 0.816826 & 64.10989 & 29.83251 & 2.012597 & 1.050034 & 2.994964 \\
\hline 8 & 0.856657 & 65.15007 & 29.00982 & 2.074742 & 0.975968 & 2.789393 \\
\hline 9 & 0.900508 & 65.80221 & 28.81139 & 1.881104 & 0.894952 & 2.610339 \\
\hline 10 & 0.961033 & 64.94268 & 29.66227 & 1.971581 & 0.865676 & 2.557794 \\
\hline
\end{tabular}

Source: Computed with the help of Eviews

\section{Highlights on Russian Economy}

Russia attracted most of capital inflows due to prices and interest rate hikes by the central bank in response to rising inflation during 2012. Capital inflows in Russia reached its peak in 2007-08. GDP is found to be increasing in the pace with capital inflows. Russia has managed to control inflation in spite of high capital inflows due to appropriate policy response by the central bank. Reduced political uncertainty of Russia in 2012 also was a contributing factor for surge in capital inflows in Russia. (Suttle et al 2012). Russia's average per capita GDP grew by 1.83 times from 1999-2009 and Russia's top performing regions have per capita GDPs comparable to western European nations and the US. Tyumen and the fast gaining Sakhalin are among this group whereas Ingushetia and Chechnya have per-capita levels on par with Ghana and Iraq, respectively. (Samir et al, 2013).

Augmented Dickey Fuller (ADF) test for Russian economy shows GCF (0.012), Inflation (0.006), GGDP (0.005), capital inflows (0.0002) and exchange rate (0.021) to be stationary at first 
difference. The results are shown in table 9. Johansen cointegration test results suggest the presence of two cointegrating equations.

Table 9: Results of Augmented Dickey Fuller test- Russia

\begin{tabular}{|c|c|c|}
\hline Variable & t-statistics & p-value \\
\hline$D(C I)$ & -5.819337 & 0.0002 \\
\hline$D(G G D P)$ & -4.159570 & 0.0054 \\
\hline$D(G C F)$ & -3.760187 & 0.0122 \\
\hline$D(I N F L)$ & -4.099071 & 0.0061 \\
\hline$D(E R)$ & -3.463421 & 0.0213 \\
\hline
\end{tabular}

Source: Computed with the help of Eviews

Table 10: Results of Johansen Cointegration test- Russia

\begin{tabular}{|c|c|c|c|}
\hline $\begin{array}{c}\text { Hypothesized } \\
\text { No. of CE(s) }\end{array}$ & Eigenvalue & $\begin{array}{c}\text { Trace } \\
\text { Statistic }\end{array}$ & Probability \\
\hline None & 0.904919 & 93.24766 & 0.0002 \\
\hline At most 1 & 0.787827 & 50.89327 & 0.0252 \\
\hline At most 2 & 0.546152 & 22.98690 & 0.2467 \\
\hline At most 3 & 0.314622 & 8.767009 & 0.3874 \\
\hline At most 4 & 0.103512 & 1.966876 & 0.1608 \\
\hline
\end{tabular}

Source: Computed with the help of Eviews

The Vector Error Correction Model (VECM) estimates of Russian economy are given in table 11. The results indicate cointegration of capital inflows with GDP and Inflation in the long run. Capital inflows in Russian economy was found to be dependent on GCF. Inflation is found to associated in the long run with GGDP and exchange rate. 
TABLE 11: ESTIMATES OF VECTOR ERROR CORRECTION MODEL

\begin{tabular}{ccc} 
CointegratingEq: & CointEq1 & CointEq2 \\
\hline \hline LNCI(-1) & 1.000000 & 0.000000 \\
GGDP(-1) & 0.000000 & 1.000000 \\
LNGCF(-1) & -7.050111 & -20.83493 \\
& $(1.05447)$ & $(3.14914)$ \\
& {$[-6.68594]$} & {$[-6.61607]$} \\
LNINFL(-1) & 2.501654 & 19.11181 \\
& $(4.30006)$ & $(12.8420)$ \\
LNER(-1) & {$[0.58177]$} & {$[1.48823]$} \\
& -1.023130 & -5.263905 \\
& $(1.36152)$ & {$[4.06613)$} \\
C & {$[-0.75146]$} & {$[-1.29457]$} \\
& 0.081451 & 0.217882
\end{tabular}

\begin{tabular}{|c|c|c|c|c|c|}
\hline Error Correction: & $\mathrm{D}(\mathrm{LNCI})$ & $\mathrm{D}(\mathrm{GGDP})$ & $\mathrm{D}(\mathrm{LNGCF})$ & D(LNINFL) & D(LNER) \\
\hline \multirow[t]{3}{*}{ CointEq1 } & -0.255192 & 0.690373 & 0.049830 & 0.021567 & 0.018122 \\
\hline & $(0.49013)$ & $(0.30464)$ & $(0.13502)$ & $(0.04231)$ & $(0.08490)$ \\
\hline & {$[-0.52066]$} & [2.26622] & {$[0.36907]$} & [0.50970] & [0.21344] \\
\hline \multirow[t]{3}{*}{ CointEq2 } & 0.244489 & 0.123781 & -0.000417 & -0.041887 & 0.055137 \\
\hline & $(0.22189)$ & $(0.04334)$ & $(0.06112)$ & $(0.01916)$ & $(0.03844)$ \\
\hline & [ 1.10184$]$ & [2.8559] & {$[-0.00682]$} & {$[-2.18661]$} & [ 1.43449] \\
\hline \multirow[t]{3}{*}{ D(LNCI $(-1))$} & 0.180175 & 0.605737 & 0.043351 & -0.003372 & -0.020596 \\
\hline & $(0.37288)$ & $(0.75328)$ & $(0.10271)$ & $(0.03219)$ & $(0.06459)$ \\
\hline & {$[0.48320]$} & [0.80413] & {$[0.42206]$} & {$[-0.10475]$} & {$[-0.31888]$} \\
\hline \multirow[t]{3}{*}{$\mathrm{D}(\mathrm{GGDP}(-1))$} & 0.063288 & -0.136652 & 0.000307 & 0.008819 & -0.017555 \\
\hline & $(0.10373)$ & $(0.48776)$ & $(0.02858)$ & $(0.00896)$ & $(0.01797)$ \\
\hline & {$[0.61011]$} & {$[-0.28016]$} & {$[0.01075]$} & [ 0.98479] & {$[-0.97695]$} \\
\hline \multirow[t]{3}{*}{$\mathrm{D}(\operatorname{LNGCF}(-1))$} & 0.252543 & -0.50642 & -0.127035 & 0.301680 & -0.110992 \\
\hline & $(0.21778)$ & $(0.4281)$ & $(0.61092)$ & $(0.19146)$ & $(0.38417)$ \\
\hline & {$[1.15960]$} & {$[-1.18294]$} & {$[-0.20794]$} & {$[1.57564]$} & {$[-0.28891]$} \\
\hline \multirow[t]{3}{*}{ D(LNINFL(-1)) } & -0.348786 & 40.05133 & 0.635282 & -0.990637 & 0.785240 \\
\hline & $(0.83758)$ & $(36.8527)$ & $(0.15899)$ & $(0.67663)$ & $(0.35765)$ \\
\hline & {$[-0.41642]$} & [ 1.08680$]$ & [3.99581] & {$[-1.46407]$} & [2.195578] \\
\hline \multirow[t]{3}{*}{ D(LNER(-1)) } & -0.631657 & 0.72965 & 0.915658 & -0.292328 & 0.728665 \\
\hline & $(0.78752)$ & $(0.5112)$ & $(0.31880)$ & $(0.41331)$ & $(0.82931)$ \\
\hline & {$[-0.80208]$} & [ 1.4274$]$ & [ 2.8722] & {$[-0.70728]$} & [0.87864] \\
\hline \multirow[t]{3}{*}{$\mathrm{C}$} & -0.139055 & 0.897017 & 0.040560 & -0.028739 & 0.034072 \\
\hline & $(0.37153)$ & $(0.74696)$ & $(0.10234)$ & $(0.03207)$ & $(0.06436)$ \\
\hline & {$[-0.37428]$} & [ 1.20089$]$ & [0.39631] & {$[-0.89599]$} & [0.52942] \\
\hline
\end{tabular}

Source: Computed with the help of Eviews

The impulse response function in Russian context suggests that with one standard deviation shock to GGDP, the response of capital inflows was positive over a period of 10 years. The response of capital inflows to shock in exchange rate was found to be steady which implies one standard deviation shock did not have much impact on capital inflows. The impact of capital inflows to shock in inflation was found to be fluctuating. Further the response of capital inflows to shock in GCF was found to be negative for forthcoming 10 years as given in figure 7 . 
FIGURE 7: IMPULSE RESPONSE FUNCTION- RUSSIA

Response of LNCI to Cholesky

One S.D. Innovations

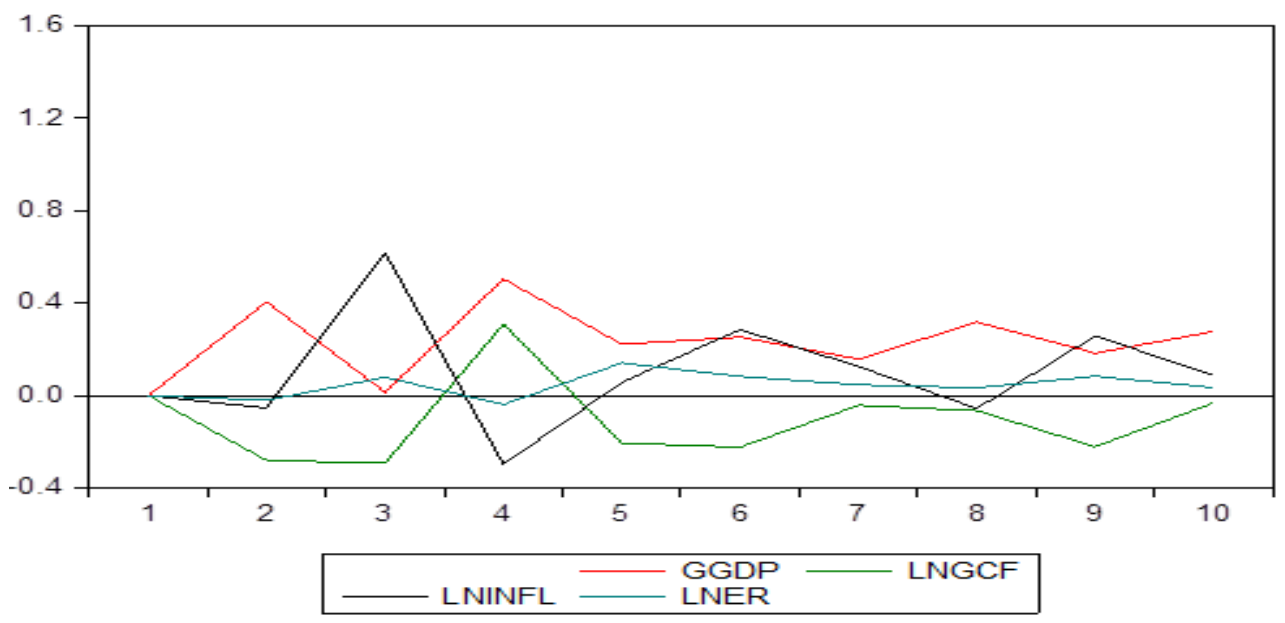

Source: Computed with the help of Eviews

Table 12: Variance Decomposition-Russia

\begin{tabular}{|c|c|c|c|c|c|c|}
\hline Period & S.E. & CI & GGDP & GCF & INFL & ER \\
\hline 1 & 1.368605 & 100.0000 & 0.000000 & 0.000000 & 0.000000 & 0.000000 \\
\hline 2 & 1.518028 & 89.30104 & 7.160944 & 3.398093 & 0.123233 & 0.016690 \\
\hline 3 & 1.840898 & 78.74056 & 4.875386 & 4.826380 & 11.36084 & 0.196826 \\
\hline 4 & 2.401598 & 79.86635 & 7.295903 & 4.496214 & 8.200834 & 0.140694 \\
\hline 5 & 2.522911 & 79.95108 & 7.388416 & 4.734796 & 7.483837 & 0.441876 \\
\hline 6 & 2.658691 & 79.08066 & 7.561134 & 4.962593 & 7.899607 & 0.496007 \\
\hline 7 & 2.853570 & 81.28772 & 6.871437 & 4.329451 & 7.053388 & 0.458005 \\
\hline 8 & 2.995565 & 81.79099 & 7.369521 & 3.975877 & 6.435090 & 0.428525 \\
\hline 9 & 3.110261 & 81.48723 & 7.184982 & 4.191926 & 6.665025 & 0.470842 \\
\hline 10 & 3.274341 & 82.48783 & 7.199459 & 3.791586 & 6.084586 & 0.436535 \\
\hline
\end{tabular}

Source: Computed with the help of Eviews

The above table shows the results of variance decomposition test for Russian economy over a period of 10 years. The test results suggest that the impact of GGDP in the short and long run was found to be steady. Inflation is found to influence capital inflows in the short run but eventually the impact tapers in the long run. Exchange rate also does not show much impact and impact of GCF is also found to be steady.

\section{CONCLUSION}

Capital flows across borders ensure efficient allocation of resources which enhances productivity and economic growth. Often, surge in capital inflows stimulate economic growth in developing countries by resulting into sharp macroeconomic fluctuations. The analysis performed brought to light interesting findings.

In Russia, the results indicated a long run cointegration of capital inflows with GCF, ER and inflation. Capital inflows in Russian economy was found to be dependent on GCF. The results of Indian economy suggested that capital inflows in the economy is associated in the long run with GGDP, inflation and ER. For Indian economy when one standard deviation shock was imposed on GGDP and exchange rate, capital inflows showed a positive trend for ten years whereas it showed a negative trend with regard to GCF. In case of response of capital inflows to inflation, it was positive for first 4 years then negative for one year and again positive. The 
impulse response function in Russian context suggests that with one standard deviation shock to GGDP, the response of capital inflows was positive over a period of 10 years. The response of capital inflows to exchange rate was found to be steady which implies one standard deviation shock did not have much impact on capital inflows whereas that of inflation was found to be fluctuating. Further the response of capital inflows to GCF was found to be negative for forthcoming 10 years.

The forecast results obtained with the help of impulse response function reveals how India and Russia together cooperate to overcome the negative impacts of the factors as described here to avoid ill effects in future.

\section{References}

Ahmed, S \& Zlate, A (2013). Capital Flows to Emerging Market Economies: A Brave New World?. Board of Governors of the Federal Reserve System, International Finance Discussion Paper No. 1081.

Arshad, M U ,Majeed, S \& Shah, A (2012). The Determinants of Capital Inflow in Developing Economies An Empirical Study of Pull Factors. Journal of Basic and Applied Scientific Research, ISSN 2090-4304.

Brana, S. \& Lahet, D. (2010). Determinants of Capital Inflows into Asia: The Relevance of Contagion Effects as Push Factors. Emerging Markets Review. www.elsevier.com

Calvo, G., Leiderman, L. \& Reinhart, C. (1993). Capital Flows and the Real Exchange Rate Appreciation in Latin America: The Role of External Factors. IMF Staff Papers.

Calvo, G.A., Leiderman, L. \& Reinhart, C.M. (1993). Capital inflows to Latin America: the role of external factors. International Monetary Fund Staff Papers 40 (1), 108-151.

Calvo, G.A., Leiderman, L. \& Reinhart, C.M. (1994a). Capital inflows to Latin America: the 1970s and 1990s. In: Bacha, E. (Ed.), Development Trade and the Environment, vol. 4. Economics in a Changing World. MacMillan Press, London, pp. 123-148.

Calvo, G.A., Leiderman, L.\& Reinhart, C.M. (1994b). The capital inflows problem: concepts and issues.

Contemporary Economic Policy 12 (3), 55-66.

Canela, M A, Collazo, E P. \&Santiso, J (2006). Capital Flows to BRIC's Countries Fundamentals or Just Liquidity?

Frankel, J. (2008). The Effect of Monetary Policy on Real Commodity Prices. In Asset Prices and Monetary Policy. Ed. John Y. Campbell, NBER, University of Chicago, Chicago. NBER Working Paper No.12713.

Fratzscher, M., Duca, M. Lo \& Straub, R. (2012). Quantitative Easing, Portfolio Choice and International Capital Flows. European Central Bank, Frankfurt.

Fratzscher, M. (2011). Capital Flows, Push Versus Pull Factors And The Global Financial Crisis, Working Paper Series No 1364.

Fratzscher, M. (2012). Capital Flows, Push versus Pull Factors and the Global Financial Crisis. Journal of International Economics. Vol. 88, no. 2: 341-356.

Government of India (2016). Ministry of External Affairs. Report on India-Russia Relations, https://www.mea.gov.in/Portal/ForeignRelation/India_Russia_Relation_DEC2016.pdf

Hooper, V. \& Kim, S. (2007). The Determinants of Capital Inflows: Does Opacity of Recipient Country Explain the Flows?. Economic Systems. Vol. 31, no. 1: 35-48.

Johansen, S. (1995). Likelihood based inference in Cointegrated Vector Autoregressive Models. New York, Oxford University Press.

Johansen, S. (1998). Statistical analysis of cointegration vectors. Journal of Economic Dynamics and Control 12, 231-254.

Johnson, A. (2005). The Effects of FDI Inflows on Host Country Economic Growth Paper in progress. International Business School Jönköping, Sweden.

Luca, O. \&Spatafora, N. (2012). Capital Inflows, Financial Development, and Domestic Investment: Determinants and Inter-Relationships. IMF Working paper 120, 1-22.

Pollock, M (2011). Capital Flows to Developing Countries - BRIC: Where the Action Is. World Bank Blogs. 
Samir, S., Ashok, K. S. \&Vivan, S. (2013). A Long-Term Vision for BRICS. Submission to the BRICS Academic Forum. Observer Research Foundation.

Sims, C. A. (19800. Macroeconomics and Reality. Econometrica 48 (1):1-48.

Sunny, D, \& Unnikrishnan, A. (2015). Pattern of capital inflows in BRICS: Aspects to ponder for policy implementation. The Journal of Developing Areas, USA, 49(6), 219-234.

Sunny, D. (2015). Do the FDI inflows affect domestic investment? Issues Before India and South Asia. The Journal of Developing Areas, USA, 49(6), 173-187.

Suttle, P., Huefner, F.\&Koepke, R. (2012) and (2013). Capital Flows to Emerging Market Economies. Institute of International Finance research note. 